\title{
Activity Based Management Sebagai Instrumen Bagi Manajemen Dalam Efisiensi Biaya
}

\author{
Jusmani ${ }^{1}$, Oktariansyah ${ }^{2}$ \\ ${ }^{1}$ Fakultas Ekonomi dan Bisnis Universitas PGRI Palembang, jusmanitawil@yahoo.co.id \\ ${ }^{2}$ Fakultas Ekonomi dan Bisnis Universitas PGRI Palembang, rianbro82@univpgri-palembang.ac.id
}

\begin{abstract}
ABSTRAK
Activity Based Management (ABM) adalah pengelolaan aktivitas untuk meningkatkan nilai (value) yang diterima oleh pelanggan dan untuk meningkatkan laba melalui peningkatan nilai (value) tersebut. Activity Based Management menggunakan Activity Based Costing sebagai sumber informasinya. Secara umum dalam pengimplementasiian Activity Based Management(ABM) ada enam tahapan utama yang harus dilakukan. Tahapan tersebut adalah mengidentifikasi aktivitas, menganalisis aktivitas, menganalisis pemicu biaya (cost driver), melakukan pembebanan biaya produksi ke tiap-tiap aktivitas, menganalisa non value added activity. Kesemua tahapan ini merupakan satu kesatuan yang harus dilakukan secara berurutan dan terencana agar implementasi dapat berjalan dengan lancar. Untuk meningkatkan efektivitas dari peninjauan proses dalam Activity Based Management (ABM), maka diperlukan perubahan orientasi kerja dan mendedikasikan lebih banyak sumber daya untuk aktivitas kerja yang bernilai tambah (value added) serta menyisihkan sumber daya yang dialokasikan untuk aktivitas kerja yang tidak memiliki nilai tambah (non-value added).
\end{abstract}

Kata kunci: Activity Based Management, Cost Driver, Value Added

\begin{abstract}
Activity Based Management ( $A B M$ ) is the management of activities to increase the value received by customers and to increase profits through increasing this value. Activity Based Management using Activity Based Costing as a source of information. In general, in implementing Activity Based Management (ABM), there are six main stages that must be carried out. These stages are identifying activities, analyzing activities, analyzing cost drivers, charging production costs for each activity, analyzing non-value added activities. All of these stages constitute one unit that must be carried out sequentially and planned so that implementation can run smoothly. To increase the effectiveness of the process review in Activity Based Management (ABM), it is necessary to change work orientation and dedicate more resources to value-added work activities and set aside resources allocated for work activities that do not have added value (non-value added)
\end{abstract}

Keywords: Activity Based Management, Cost Driver, Value Added

\section{A. PENDAHULUAN}

Pada saat ini, persaingan global yang semakin kompetitif menyebabkan lingkungan bisnis yang dihadapi oleh manajemen semakin dinamis dengan perubahan yang pesat. Oleh karena itu, perusahaan yang beroperasi dalam lingkungan bisnis harus memiliki kemampuan untuk melakukan adaptasi dan perubahan agar dapat mempertahankan kelangsungan hidupnya.

Untuk mempertahankan kelangsungan hidupnya, suatu perusahaan harus dapat mencapai tujuannya yaitu memaksimalkan laba usahanya. Biaya yang dikeluarkan oleh perusahaan harus benar-benar biaya yang memberi nilai tambah bagi produk sehingga tidak akan ada pemborosan biaya. Oleh karena itu, efisiensi biaya mempunyai arti penting bagi perusahaan dalam mempertahankan keberadaannya di dunia bisnis, juga dalam upaya menghadapi persaingan global yang semakin tajam. Salah satu cara yang dapat digunakan perusahaan untuk 
mencapai efisiensi biaya adalah melalui manajemen berbasis aktivitas atau Activity Based Management (ABM).

Activity Based Management (ABM) adalah pendekatan terpadu dan menyeluruh yang membuat perhatian manajemen berpusat pada aktivitas yang dilakukan, dengan tujuan meningkatkan nilai pelanggan dan laba yang diperoleh karena memberikan nilai tersebut (Hansen dan Mowen, 2009:478). Konsep Activity Based Management (ABM) sendiri merupakan kelanjutan dari konsep Activity Based Costing $(\mathrm{ABC})$, sehingga keduanya mempunyai hubungan yang sangat erat.

Activity Based Costing (ABC) lebih memfokuskan pada penentuan biaya yang timbul karena adanya aktivitas usaha, sementara Activity Based Management (ABM) memfokuskan pada pengelolaan aktivitas untuk mempromosikan efisiensi dan efektivitas bisnis, serta untuk meningkatkan tidak hanya nilai (value) yang diterima oleh pelanggan tetapi juga memberikan laba bagi perusahaan. Hal inilah yang akan menjadi pokok bahasan dalam makalah ini, dimana akan dibahas lebih lanjut mengenai hubungan Activity Based Costing dan Activity Based Management dan penerapan analisa nilai proses berdasarkan pada penelitian-penelitian yang telah ada sebelumnya.

\section{B. LANDASAN TEORI}

\section{1) Definisi Activity-Based Management}

Activity-Based Management (ABM) adalah suatu pendekatan di seluruh sistem dan terintegrasi, yang memfokuskan perhatian manajemen pada berbagai aktivitas, dengan tujuan meningkatkan nilai untuk pelanggan dan laba sebagai hasilnya (Hansen dan Mowen, 2009; 11).

Menurut Mulyadi (2009;731), Activity-Based Management (ABM) adalah pendekatan manajemen yang memusatkan pengelolaan pada aktivitas dengan tujuan untuk melakukan improvement berkelanjutan terhadap value yang dihasilkan bagi customer, dan laba yang dihasilkan dari penyedia value tersebut.

Sedangkan menurut Blocher (2011;239), Activity-Based Management (ABM) analisis aktivitas yang digunakan untuk memperbaiki nilai produk atau jasa bagi pelanggan dan meningkatkan keuntungan perusahaan.

Berdasarkan definisi-definisi diatas, ABM mempunyai dua frasa penting, yaitu: (1) manajemen berbasis aktivitas berfokus pada pengelolaan aktivitas untuk meningkatkan nilai yang diterima oleh konsumen, dan (2) pemusatan pengelolaan pada aktivitas untuk menghasilkan laba dari penyedia nilai tersebut.

\section{2) Tujuan dan Manfaat Activity-Based Management}

ABM merupakan pusat dari sistem manajemen biaya, dan oleh karena itu untuk mengelola organisasi atau perusahaan dengan baik, harus menekankan pada ABM. ABM bertujuan untuk meningkatkan nilai produk atau jasa yang diterima oleh para konsumen, dan oleh karena itu dapat digunakan untuk mencapai laba dengan menyediakan nilai tambah bagi konsumennya.

Manfaat yang diperoleh dengan menggunakan ABM adalah manajemen dapat menentukan wilayah untuk melakukan perbaikan operasi, mengurangi biaya, atau meninggkatkan nilai bagi pelanggan. Dengan mengidentifikasi sumber daya yang dipakai konsumen, produk, dan aktivitas, ABM memperbaiki fokus manajemen atas faktor-faktor kunci perusahaan dan meningkatkan keunggulan kompetitif (Blocher, $2011 ; 239)$ 
Manfaat ABM menurut Supriyono (1999; 356) adalah:

1. Mengukur kinerja keuangan dan pengoperasian (non keuangan) organisasi dan aktivitas-aktivitasnya.

2. Menentukan biaya-biaya dan profitabilitas yang benar untuk setiap tipe produk dan jasa.

3. Mengidentifikasikan aktivitas-aktivitas dan mengendalikannya.

4. Mengelompokkan aktivitas-aktivitas bernilai tambah dan tidak bernilai tambah.

5. Mengefisienkan aktivitas bernilai tambah dan mengeliminasi aktivitas-aktivitas tidak bernilai tambah.

6. Menjamin bahwa pembuatan keputusan, perencanaan dan pengendalian didasarkan pada isu-isu bisnis yang keluar dan tidak semata berdasar informasi keuangan.

7. Menilai penciptaan rangkaian nilai tambah (value-added chain) untuk memenuhi kebutuhan dan kepuasan konsumen.

\section{3) Dimensi Activity-Based Management}

Activity-Based Management menekankan pada biaya berdasarkan aktivitas atau Activity-Based Costing (ABC) dan analisis nilai proses. Jadi, Activity-Based Management memiliki dua dimensi, yaitu dimensi biaya dan dimensi proses (Hansen dan Mowen, 2009; 487).

1. Dimensi Biaya

Dimensi biaya adalah dimensi $A B M$ yang memberikan informasi biaya mengenai sumber, aktivitas, produk, dan pelanggan. Dimensi biaya ini bertujuan untuk memperbaiki keakuratan pembebanan biaya. Dimensi biaya atau dimensi Activity-Based Costing (ABC), didasarkan pada ABC generasi kedua yang merupakan perkembangan lebih lanjut dari $A B C$ generasi pertama. $A B C$ generasi pertama adalah sistem penentuan biaya produk yang terdiri atas dua tahap yaitu: (1) melacak biaya pada berbagai aktivitas, dan (2) membebankan biaya pada produk.

$A B C$ semula diakui sebagai metode untuk menyempurnakan ketelitian biaya produk, namun $A B C$ generasi kedua merupakan sistem pengukuran kinerja yang bersifat komprehensif yang digunakan sebagai sumber informasi utama Activity-Based Management (ABM). ABC generasi kedua adalah metodologi untuk mengukur dan menyediakan informasi mengenai biaya sumber-sumber, aktivitas- aktivitas, dan pembebanan biaya pada objek-objek biaya. Asumsi yang mendasari adalah: (1) objek-objek biaya menciptakan perlunya aktivitas-aktivitas, dan (2) aktivitas-aktivitas menciptakan perlunya sumber-sumber. ABC juga merupakan sistem yang bermanfaat untuk mengorganisasi dan mengkomunikasikan informasi.

2. Dimensi Proses

Dimensi proses atau analisis nilai proses adalah dimensi ABM yang memberikan informasi tentang aktivitas apa yang dikerjakan, mengapa dikerjakan dan seberapa baik dikerjakannya. Tujuan dimensi proses adalah pengurangan biaya. Dimensi inilah yang memberikan kemampuan untuk mengukur perbaikan berkelanjutan.

Dimensi proses adalah dimensi model ABM yang berisi informasi kinerja mengenai pekerjaan yang dilaksanakan dalam organisasi sehingga mencakup : (a) analisis penyebab biaya, (b) analisis aktivitas-aktivitas, dan (c) evaluasi kinerja dengan menggunakan informasi dari ABC. Dimensi proses 
menyediakan informasi mengenai pekerjaan yang dilakukan dalam suatu aktivitas dan hubungan antara pekerjaan tersebut dengan aktivitas lainnya. Proses adalah serangkaian aktivitas yang terkait untuk melaksanakan tujuan tertentu.

\section{4) Aktivitas}

\section{Definisi Aktivitas}

Aktivitas adalah perbuatan, tindakan atau pekerjaan spesifik yang dilakukan dalam suatu organisasi Blocher (2011; 221). Menurut Supriyono (1999; 77), aktivitas adalah kombinasi manusia, teknologi, bahan mentah, metode dan lingkungan yang memproduksi produk atau jasa tertentu. Aktivitas itu menunjukkan apa yang dilakukan oleh suatu perusahaan atau organisasi, yaitu cara perusahaan atau organisasi menggunakan waktu untuk melaksanakan proses untuk menghasilkan keluaran atau output dari proses dan mencapai tujuan organisasi atau perusahaan. Salah satu unsur organisasi adalah manusia, perubahan organisasi mengakibatkan perubahan mengenai apa yang dikerjakan manusia, sehingga mengubah aktivitas.

Berkaitan dengan hal ini, dapat dikatakan pula bahwa aktivitas merupakan suatu proses yang mengkonsumsi sumber daya untuk menghasilkan output. Pada intinya fungsi dari aktivitas adalah untuk mengubah sumberdaya (material, tenaga kerja, teknologi) menjadi output (barang atau jasa).

\section{Klasifikasi Aktivitas}

Akivitas dapat dikelompokkan menjadi dua, yaitu aktivitas bernilai tambah dan aktivitas tidak bernilai tambah. Kedua aktivitas ini biasanya terjadi pada perusahaan manufaktur ataupun perusahaan jasa.

Aktivitas Bernilai Tambah

Aktivitas bernilai tambah adalah aktivitas-aktivitas yang diharuskan untuk melaksanakan bisnis atau menciptakan nilai yang dapat memuaskan bagi para konsumennya (Supriyono, 1999; 377). Menurut Hansen dan Mowen (2009:489), aktivitas bernilai tambah adalah aktivitas-aktivitas yang diperlukan untuk dipertahankan dalam bisnis. Aktivitas ini harus terus dipertahankan oleh perusahaan, karena aktivitas inilah yang menjadikan suatu produk atau jasa lebih kompetitif dipasar. Jika aktivitas bernilai tambah dieliminasi, akan mengurangi nilai yang akan didapat oleh konsumen, sehingga konsumen tidak lagi membeli atau mengkonsumsi produk atau jasa perusahaan tersebut. Dengan kata lain, perusahaan tersebut akan mengalami kekalahan persaingan di dalam pasar. Aktivitas bernilai tambah menimbulkan biaya aktivitas bernilai tambah, yaitu biaya yang digunakan untuk melaksanakan aktivitas-aktivitas bernilai tambah. Aktivitas dapat dikelompokkan kedalam aktivitas bernilai tambah apabila secara bersamaan memenuhi ketiga kondisi berikut ini (Hansen dan Mowen, 2009;489):

a. Aktivitas yang menghasilkan perubahan,

b. Perubahan tersebut tidak dapat dicapai oleh aktivitas yang sebelumnya,

c. Aktivitas tersebut memungkinkan aktivitas lain untuk dilakukan.

\section{$>\quad$ Aktivitas Tidak Bernilai Tambah}

Menurut Supriyono (1999; 377), aktivitas tidak bernilai tambah adalah aktivitasaktivitas yang tidak perlu atau aktivitas-aktivitas yang perlu namun tidak efisien dan dapat disempurnakan. Sedangkan menurut Hansen dan Mowen (2009; 490), 
aktivitas tidak bernilai tambah adalah semua aktivitas selain aktivitas yang sangat penting untuk dipertahankan dalam bisnis, sehingga dianggap sebagai aktivitas yang tidak diperlukan.

Berdasarkan beberapa definisi aktivitas tidak bernilai tambah tersebut, tentunya perusahaan akan berusaha untuk mengeliminasi aktivitas tidak bernilai tambah, karena hanya menambah biaya yang tidak berguna dan menghalangi kinerja perusahaan. Suatu aktivitas dikelompokkan kedalam aktivitas tidak bernilai tambah apabila aktivitas tersebut tidak dapat memenuhi salah satu dari ketiga kriteria aktivitas bernilai tambah yang telah disebutkan sebelumnya.

Perusahaan mengelompokkan aktivitas kedalam aktivitas bernilai tambah dan kedalam aktivitas tidak bernilai tambah, dengan tujuan untuk dapat meminimumkan biaya yang terjadi akibat aktivitas tidak bernilai tambah, dengan cara mengeliminasi aktivitas tersebut. Aktivitas tidak bernilai tambah yang tidak dieliminasi akan menyebabkan meningkatnya biaya produksi perusahaan. Aktivitas tidak bernilai tambah menimbulkan biaya aktivitas tidak bernilai tambah, yaitu biaya yang timbul karena adanya aktivitas yang tidak bernilai tambah.

\section{e. Pengukuran Kinerja Aktivitas}

Pengukuran kinerja aktivitas dirancang untuk melihat bagaimana suatu aktivitas dan proses dilaksanakan, dan hasil yang diperolehnya. Pengukuran kinerja kativitas juga dirancang untuk mengungkapkan apakah dilaksanakan improvement berkelanjutan terhadap aktivitas untuk menghasilkan nilai bagi konsumen. Pengukuran kinerja aktivitas berpusat pada tiga dimensi: efisiensi, kualitas dan waktu (Mulyadi dan Johny Setyawan, 2001; 629). Efisiensi memfokuskan hubungan antara masukan dengan keluaran aktivitas. Kualitas berkaitan dengan apakah sejak pertama kali aktivitas telah dilaksanakan dengan benar. Waktu digunakan dalam menjalankan aktivitas. Waktu ini sangat penting, karena semakin lama waktu yang diperlukan oleh suatu aktivitas, maka semakin banyak sumber daya yang dikonsumsi oleh aktivitas tersebut.

Pengukuran kinerja aktivitas dilaksanakan baik dalam bentuk kinerja keuangan dan non keuangan. Ukuran kinerja keuangan harus dapat menyediakan informasi mengenai dampak perubahan kinerja aktivitas yang dinyatakan dalam satuan uang (Supriyono, 2013; 390). Oleh karena itu, ukuran keuangan harus dapat menunjukkan pengurangan biaya yang sesungguhnya dicapai. Untuk memungkinkan manajemen mengelola aktivitas, biaya harus dipisahkan kedalam biaya bernilai tambah dan biaya tidak bernilai tambah. Pemisahaan biaya ini diperlukan agar manajemen (Mulyadi dan Johny Setyawan, 2001; 629):

1) Dapat memusatkan perhatian mereka terhadap pengurangan dan akhirnya penghilangan biaya tidak bernilai tambah

2) Menyadari besarnya pemborosan yang sekarang sedang terjadi.

3) Memantau efektivitas program pengelolaan aktivitas dengan menyajikan biaya- biaya tidak bernilai tambah kepada manajemen dalam bentuk perbandingan antarperiode.

Ukuran kinerja non-keuangan atau ukuran operasional adalah ukuran-ukuran kinerja penting non-keuangan untuk meningkatkan keterlibatan dan pemberdayaan karyawan (Supriyono, 2013; 404). Waktu merupakan ukuran kinerja nonkeuangan. Dua karakteristik penting dalam ukuran kinerja waktu adalah (Supriyono, 2013; 404): (1) reliabilitas, reliabilitas waktu adalah pengiriman keluaran aktivitas tepat 
waktu dan (2) ketertanggapan, ketertanggapan adalah kemampuan perusahaan atau kelompok aktivitas dalam merespon permintaan konsumennya.

\section{METODELOGI PENELITIAN}

Metode penelitian kualitatif menurut Sugiyono (2018:8) adalah Penelitian yang digunakan untuk menyelidiki, menemukan, menggambarkan, dan menjelaskan kualitas atau keistimewaan dari pengaruh sosial yang tidak dapat dijelaskan, diukur atau digambarkan melalui pendekatan kuantitatif.

Metode penelitian yang akan digunakan dalam artikel ini adalah analisis deskriptif kualitatif yaitu pembahasan secara sistematis, factual dan akurat mengenai suatu objek yang diteliti.

\section{PEMBAHASAN}

\section{1) Konsep Dasar Model CAM-I Cross}

Secara umum kita mengenal konsep Activity Based Management (ABM) sebagai suatu bentuk pengelolaan aktivitas untuk meningkatkan nilai (value) yang diterima oleh pelanggan dan untuk meningkatkan laba melalui peningkatan nilai (value) tersebut. Pada dasarnya Activity Based Management menggunakan Activity Based Costing sebagai sumber informasinya. Hal ini senada dengan apa yang diungkapkan dalam jurnal yang berjudul The ABC's of Activity Based Management $(A B M)$ in The Petroleum Industry yang ditulis oleh Andrew D. Muras pada tahun 2000. Penelaahan Activity Based Costing (ABC) sebagai sumber informasi bagi Activity Based Management (ABM) secara keseluruhan dapat dideskripsikan pada model berikut ini:

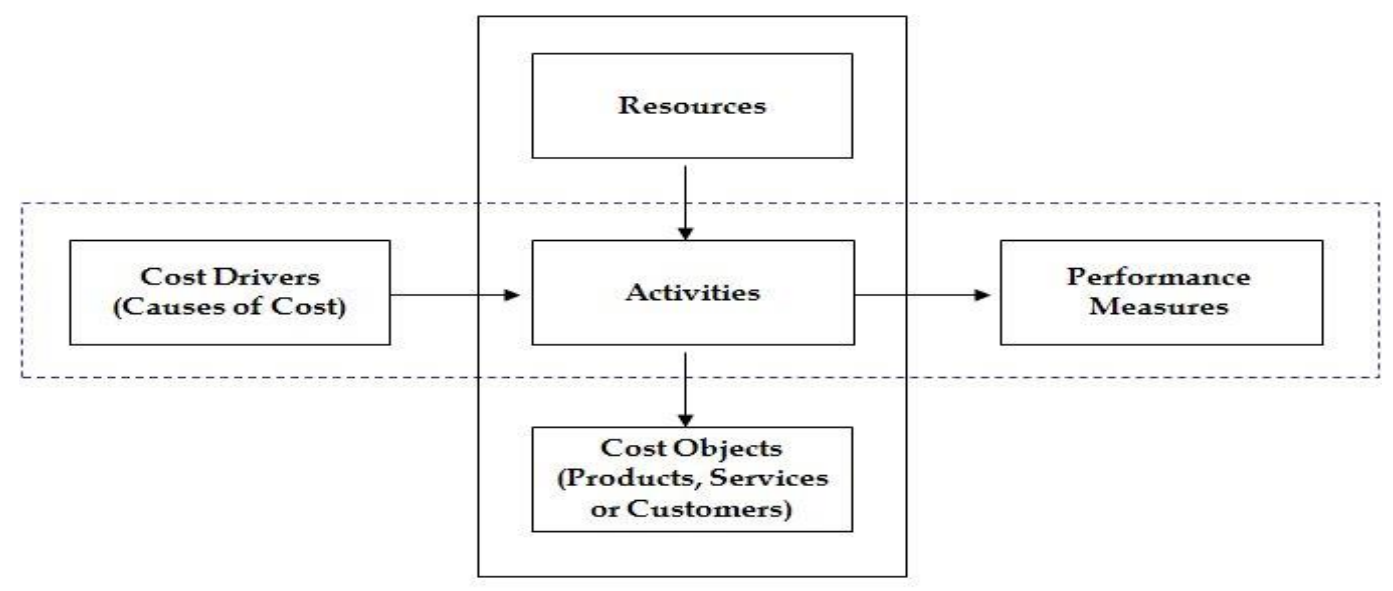

The CAM-I Cross
CAM-I (Consortium for Advanced Management-International)

Model CAM-I Cross ini menunjukkan ada dua arus utama yaitu arus vertikal dan arus horisontal. Arus vertikal merupakan arus biaya yang dimulai dari bahan baku menuju ke aktivitas dan kemudian ke objek biaya. Arus vertikal inilah yang biasa disebut sebagai Activity Based Costing (ABC) dengan tujuan utama objek biaya, dimana kita akan mengkalkulasikan biaya yang terjadi. Activity Based Costing (ABC) hanya efektif apabila tujuannya hanya untuk mengetahui biaya yang dikeluarkan oleh aktivitas bisnis sebuah perusahaan. 
Kemudian arus horizontal pada model CAM-I Cross dimulai dari cost driver (pemicu biaya) menuju ke aktivitas dan kemudian berakhir di pengukuran kinerja. Arus horizontal inilah yang biasa disebut sebagai Activity Based Management (ABM). Pada dasarnya Activity Based Management (ABM) digunakan apabila tujuannya tidak hanya melihat biaya yang ditimbulkan terhadap suatu aktivitas, tetapi juga untuk meningkatkan kinerja biaya atau pengefisiensian biaya dalam sebuah proses aktivitas. Jadi peninjauan proses dalam Activity Based Management (ABM) merupakan komponen yang paling penting dalam pengefisiensian biaya yang timbul dari aktivitas bisnis.

Dalam peninjauan proses, setiap aktivitas akan dianalisis untuk mengidentifikasi dan menghitung pemicu biaya atau sumber yang menyebabkan timbulnya suatu aktivitas yang harus dijalankan. Secara umum, analisis ini sendiri dapat dilakukan dengan beberapa metode seperti diagram affinity dan flow-charting. Setelah pemicu biaya dapat diukur, maka penentuannya dapat dilakukan pada nilai yang terkandung dalam sebuah aktivitas atau tugas. Untuk meningkatkan efektivitas dari peninjauan proses dalam Activity Based Management (ABM), maka diperlukan perubahan orientasi kerja dan mendedikasikan lebih banyak sumber daya untuk aktivitas kerja yang bernilai tambah (value added) serta menyisihkan sumber daya yang dialokasikan untuk aktivitas kerja yang tidak memiliki nilai tambah (non-value added).

\section{2) Hubungan Activity Based Costing (ABC) dengan Activity Based Management (ABM)}

Secara harafiah model CAM-1 Cross juga mengklarifikasi perbedaan utama dari Activity Based Costing (ABC) dengan Activity Based Management (ABM) dalam dimensi yang lebih spesifik. Menurut model ini, Activity Based Costing (ABC) lebih dilihat sebagai sebuah metodologi yang digunakan untuk mengukur biaya berdasarkan tingkatan aktivitasnya. Secara spesifik model ini menyatakan bahwa sumber daya digunakan untuk suatu aktivitas berdasarkan pada tingkat penggunaannya dan aktivitas itu sendiri akan dijadikan sebagai objek pengenaan biaya berdasarkan pada tingkat konsumsi sumber dayanya.

Sementara itu, Activity Based Management (ABM) lebih dilihat sebagai suatu disiplin ilmu yang menfokuskan diri pada pengelolaan proses aktivitas guna meningkatkan nilai yang akan diterima oleh konsumen dan mendapatkan keuntungan dari nilai tersebut. Secara harafiah apa yang diungkapkan model CAM-I Cross ini senada dengan beberapa definisi sebelumnya mengenai konsep Activity Based Management (ABM) dalam dimensi yang lebih luas. Jadi konsep Activity Based Costing lebih kepada "berapa biaya aktivitasnya", sementara Activity Based Management (ABM) lebih condong kepada pendekatan proses yaitu "apa yang menyebabkan suatu biaya timbul".

Walaupun keduanya berbeda tapi pada dasarnya saling berhubungan, dimana data Activity Based Costing (ABC) digunakan oleh Activity Based Management (ABM) dalam merevisi dan meningkatkan efisiensi penggunaan sumber daya. Jadi dari model CAM-I Cross kita sebenarnya dapat melihat adanya sebuah hubungan positif antara Activity Based Costing (ABC) dan Activity Based Management (ABM). Dimana kedua konsep tersebut pada dasarnya merupakan satu kesatuan, walaupun secara struktual Activity Based Costing (ABC) dan Activity Based Managemen (ABM) dipakai untuk tujuan yang berbeda. 


\section{3) Penerapan Analisa Nilai Proses}

Secara umum dalam pengimplementasiian Activity Based Management (ABM) ada enam tahapan utama yang harus dilakukan. Tahapan tersebut adalah mengidentifikasi aktivitas, menganalisis aktivitas, menganalisis pemicu biaya (cost driver), melakukan pembebanan biaya produksi ke tiap-tiap aktivitas, menganalisa non value added activity. Kesemua tahapan ini merupakan satu kesatuan yang harus dilakukan secara berurutan dan terencana agar implementasi dapat berjalan dengan lancar.

Berikut akan disajikan ilustrasi mengenai pengimplementasian Activity Based Management (ABM) pada sebuah perusahaan gula. Langkah pertama yang dilakukan adalah mengidentifikasi aktivitas perusahaan gula. Identifikasi ini dilakukan untuk melihat tatanan aktivitas apa saja yang ada dalam perusahaan gula ini. Contohnya sebagai berikut:

Tabel Daftar Aktivitas Produksi

\begin{tabular}{|c|c|}
\hline BAGIAN & AKTIVITAS \\
\hline PERSIAPAN & $\begin{array}{l}\text { 1) Memelihara tebu dari kebun dengan angkutan } \\
\text { truk } \\
\text { 2) Penyeleksian tebu oleh Tim MBS (Manis, } \\
\text { Bersih, Segar) } \\
\text { 3) Mengirim tebu ke timbangan } \\
\text { 4) Menimbang tebu } \\
\text { 5) Mengatur tebu yang sudah ditimbang dalam } \\
\text { emplasemen } \\
\text { 6) Memindahkan tebu yang sudah di timbang ke } \\
\text { meja tebu }\end{array}$ \\
\hline PENGOLAHAN & $\begin{array}{l}\text { 1) Memotong tebu menjadi potongan kecil-kecil } \\
\text { 2) Melaksanakan proses penggilingan tebu } \\
\text { 3) Mencampur bahan kimia } \\
\text { 4) Melaksanakan proses ketelan / pemanasan } \\
\text { 5) Mesin } \\
\text { 6) Melaksanakan proses pemurnian } \\
\text { 6) Melaksanakan proses penguapan } \\
\text { 7) } \\
\text { 8) Melaksanakanan putaran } \\
\text { 9) Perbaikan dan pemeliharaan mesin pengolahan } \\
\text { 10) Perbaikan dan pemeliharaan bangunan pabrik }\end{array}$ \\
\hline PENYELESAIAN & $\begin{array}{l}\text { 1) Melaksanakan proses pengeringan } \\
\text { 2) Menyeleksi ukuran kristal } \\
\text { 3) Pengemasan / packing } \\
\text { 4) Memeriksa kualitas barang jadi } \\
\text { 5) Mengirim dan menyimpan barang jadi } \\
\text { 6) ke gudang }\end{array}$ \\
\hline
\end{tabular}

Tahapan kedua yang dilakukan adalah menganalisis aktivitas berdasarkan pada data yang telah dikumpulkan pada tahap pertama. Analisis yang dilakukan bertujuan untuk mengklasifikasikan aktivitas apa saja yang termasuk dalam kategori value added activty dan aktivitas apa saja yang termasuk dalam non value added activity. 
Tabel Klasifikasi Aktivitas

\begin{tabular}{|c|c|c|c|c|}
\hline \multirow[b]{2}{*}{ No } & \multirow[b]{2}{*}{ Aktivitas } & \multirow[b]{2}{*}{$\begin{array}{l}\text { Value } \\
\text { Added }\end{array}$} & \multicolumn{2}{|c|}{ Non Value Added } \\
\hline & & & $\begin{array}{c}\text { Yang Bisa } \\
\text { Dihilangkan }\end{array}$ & $\begin{array}{c}\text { Yang Tidak } \\
\text { Dapat } \\
\text { Dihilangkan }\end{array}$ \\
\hline $\begin{array}{l}6 \\
7 \\
8 \\
9 \\
10 \\
11 \\
12 \\
13 \\
14 \\
15 \\
16 \\
17 \\
18 \\
19 \\
20\end{array}$ & $\begin{array}{l}\text { Menerima tebu dari kebun dengan angkutan truk } \\
\text { Penyeleksian tebu oleh Tim MBS (Manis, Bersih, } \\
\text { Segar) } \\
\text { Mengirim tebu ke timbangan } \\
\text { Menimbang tebu } \\
\text { Mengatur tebu yang sudah ditimbang dalam } \\
\text { emplasemen } \\
\text { Memindahkan tebu yang sudah di timbang ke } \\
\text { meja tebu } \\
\text { Memotong tebu menjadi potongan kecil-kecil } \\
\text { Melaksanakan proses penggilingan tebu } \\
\text { Mencampur bahan kimia } \\
\text { Melaksanakan proses ketelan / pemanasan mesin } \\
\text { Melaksanakan proses pemurnian } \\
\text { Melaksanakan proses penguapan } \\
\text { Melaksanakan proses masakan } \\
\text { Melaksanakan putaran } \\
\text { Perbaikan dan pemeliharaan mesin pengolahan } \\
\text { Perbaikan dan pemeliharaan bangunan pabrik } \\
\text { Melaksanakan proses pengeringan } \\
\text { Menyeleksi ukuran kristal } \\
\text { Pengemasan / packing } \\
\text { Memeriksa kualitas barang jadi } \\
\text { Mengirim dan menyimpan barang jadi ke gudang }\end{array}$ & $\begin{array}{l}V \\
V \\
V \\
V \\
V \\
V \\
V \\
V \\
V \\
V \\
V \\
V \\
V\end{array}$ & $\begin{array}{l}V \\
V\end{array}$ & V \\
\hline
\end{tabular}

Tahapan ketiga adalah menganalisis pemicu biaya (cost driver) yang ada pada perusahaan gula ini. Analisis pemicu biaya diperlukan dalam upaya untuk mengidentifikasi faktor-faktor penyebab timbulnya biaya aktivitas dari aktivitas yang bernilai tambah maupun aktivitas yang tidak bernilai tambah.

Tabel Identifikasi Pemicu Biaya

\begin{tabular}{|c|c|}
\hline Biaya Aktivitas & Pemicu Biaya \\
\hline $\begin{array}{l}\text { - Biaya bahan pembantu } \\
\text { - Biaya tenaga kerja tidak langsung } \\
\text { - Biaya pemeliharaan mesin dan peralatan } \\
\text { - Biaya pemeliharaan bangunan } \\
\text { - Biaya penyusutan mesin } \\
\text { - Biaya penyusutan bangunan pabrik } \\
\text { - Biaya asuransi mesin dan peralatan } \\
\text { - Biaya asuransi bangunan pabrik } \\
\text { - Biaya air } \\
\text { - Biaya listrik } \\
\text { - Biaya bahan bakar } \\
\text { - Biaya pengemasan } \\
\text { - Biaya instalasi limbah } \\
\text { - Biaya angkut dan menyimpan } \\
\text { barang jadi ke gudang }\end{array}$ & $\begin{array}{l}\text { - Pembebanan langsung } \\
\text { - Jumlah TKTL } \\
\text { - Pembebanan langsung } \\
\text { - Luas lahan yang digunakan } \\
\text { - Pembebanan langsung } \\
\text { - Luas lahan yang digunakan } \\
\text { - Jumlah harga mesin } \\
\text { - Luas lahan yang digunakan } \\
\text { - Jumlah pemakaian air (m3) } \\
\text { - Jumlah kilowatt hours } \\
\text { - Pembebanan langsung } \\
\text { - Jumlah unit packing } \\
\text { - Persentase limbah yang dihasilkan } \\
\text { - Pembebanan langsung }\end{array}$ \\
\hline
\end{tabular}

Tahap keempat adalah melakukan pembebanan biaya produksi ke tiap-tiap aktivitas. Berdasarkan penentuan pengukuran aktivitas, maka akan dilakukan 
penelusuran biaya ke tiap-tiap aktivitas untuk menentukan biaya aktivitas. Setelah hal ini dilakukan maka tahap kelimanya adalah menganalisa non value added activity. Hal ini dilakukan untuk mengeliminasi atau mengurangi segala bentuk aktivitas yang tidak memiliki nilai tambah dan walaupun dihilangkan tidak akan berpengaruh banyak.

\section{E. KESIMPULAN}

Dalam makalah ini dapat disimpulkan bahwa sebenarnya Activity Based Management (ABM) merupakan instrumen utama bagi pihak manajemen dalam melakukan pengefisiensian biaya yang berhubungan dengan aktivitas bisnis yang dilakukan oleh sebuah perusahaan. Efisiensi biaya aktivitas ini dapat tercapai dengan cara mengeliminasi aktivitas-aktivitas apa saja yang tidak memiliki nilai tambah (non-value added activity) yang dapat dihilangkan. Hal ini akan membuat biaya aktivitas yang tidak diperlukan akan hilang dan berujung pada efisiensi biaya itu sendiri.

\section{DAFTAR PUSTAKA}

Blocher, Edward J, David E. Stout, dan Gary Cokins. (2011). Manajemen Biaya Penekanan Strategis. Jilid 1 Edisi 5. Jakarta: Salemba Empat.

Hansen, Mowen. (2009). Akuntansi Manajerial (Managerial Accounting). Jakarta: Salemba Empat.

Mulyadi. (2009). Akuntansi Manajemen Konsep, Manfaat, \& Rekayasa. Jakarta: Salemba Empat.

Mulyadi, Setyawan, J. (2001). Sistem Perencanaan dan Pengendalian Manajemen. Yogyakarta: Aditya Media.

Sugiyono. (2018). Metode Penelitian Kuantitatif Kualitatif Dan R\&D . Bandung: Alfabeta.

Supriyono. (2013). Manajemen Biaya Suatu Reformasi Pengelolaan Bisnis. Buku 1 Edisi 1. Yogyakarta: BPFE. 